Article

\title{
Hydrological Model for Sustainable Development in the Aral Sea Region
}

\author{
Vladimir F. Krapivin ${ }^{1}$, Ferdenant A. Mkrtchyan ${ }^{1, *}$ and Gilbert L. Rochon ${ }^{2,3,4}$ \\ 1 Kotelnikov Institute of Radioengineering and Electronics, Russian Academy of Sciences, Vvedensky Sq. 1, \\ Fryazino, 141190 Moscow Region, Russia; vkrapivin_36@mail.ru \\ 2 Adjunct Professor, Department of Global Health Management and Policy, Tulane University School of Public \\ Health and Tropical Medicine, New Orleans, LA 70112, USA; rochon.gilbert@gmail.com \\ 3 Research Scientist, Department of Public Health Sciences, Xavier University of Louisiana, LA 70125, USA \\ 4 Senior Consultant, MSF Global Solutions, LLC, New Orleans, LA 70113, USA \\ * Correspondence: ferd47@mail.ru; Tel.: +7-496-5652558
}

Received: 3 June 2019; Accepted: 30 September 2019; Published: 22 October 2019

\begin{abstract}
Possible scenarios of the Aral Sea crisis solution are discussed, and a new scenario is proposed. Previous scenarios have provided for the transfer of water from Siberian Rivers to Central Asia and the restriction of unsustainable expansion of irrigation in this region. The scenario proposed in this paper is partly based on the use of Caspian water evaporators located on the eastern coast of the Caspian Sea. Engineering realization of this scenario needs only the construction of the drainage system for the runoff of Caspian waters to the natural evaporators, between which Kara-Bogaz-Gol is the functioning evaporator. This paper shows that realization of this scenario allows the rescue of the Aral Sea and normalization of the water balance in Central Asia. Under this, as the simulation modeling results show, there exist different versions of the scenario depending on the area of evaporators and restrictions for the runoff of Amu Darya and Syr Darya waters to the irrigation systems. Calculation results show that the Aral Sea could be restored within 90-240 years depending on the scenario versions. With only Kara-Bogaz-Gol as the evaporator, the Aral Sea cannot be restored within a century. Additionally, if the anthropogenic runoff of river waters was decreased by 10 percent, the Aral Sea would be restored over about 90 years. Possible versions of the recovery scenario are discussed and assessed.
\end{abstract}

Keywords: Aral Sea; evaporator; irrigation; scenario; water cycle; hydrological sustainability

\section{Introduction}

The water balance of Central Asia is widely discussed by many authors and is studied in different institutes, such as the Central Asian Institute for Applied Geosciences, the Faculty of Geography in the Moscow State University, the Department of Geography in the Western Michigan University, etc. [1-12]. The present state of the Aral Sea reflects the catastrophic processes in the Central Asia water balance which are connected with both global climate change and anthropogenic processes, such as the realization of the Kara-Kum Channel Project and damming the water outflow from the Caspian Sea to the Kara-Bogaz-Gol Bay [10,13-17].

The state of the Aral Sea provokes the anxiety of governments of Central Asia and neighboring countries. In actuality, the Aral Sea drying can significantly impact the regional climate, as well as having an influence on the global climate $[18,19]$. A major problem of confronting countries in Central Asia is the redistribution of water resources and optimization of their usage [20,21]. This problem has arisen because of the diversion of the Amu Darya and Syr Darya rivers for agricultural purposes and energy production. Unfortunately, this action was initially realized without a scientific environmental 
impact assessment. Continuation of current policies and practices, with respect to the regional water cycle, is counter-productive to an effective resolution of the existing problems [22,23].

Optimization of using the Syr Darya and Amu Darya waters requires the coordination of strategic solutions by five countries of Central Asia concerning the distribution of restricted water resources [24]. Regional water crises take place as a result of the absence of effective agreements among Kazakhstan, Kyrgyzstan, Tajikistan, Turkmenistan and Uzbekistan, addressing the coordinated use of the main water source-the Amy Darya River [21]. Over the last century, the Soviet Union has constructed a system of dams and irrigation channels to solve the irrigation problem that was stimulated by the rapidly growing population. The transfer of water from Siberian Rivers to the Aral Sea Basin was discussed as one possible solution of the water crisis in Central Asia [7,8,11,12]. The Soviet Union's disintegration closed the discussion on the resolution of this problem and the Aral Sea water level continues to drop. The water resources of Amy Darya and Syr Darya are formed within the framework of their drainage basin of $534,739 \mathrm{~km}^{2}$ and mainly in the high mountains [25]. Data approximations with respect to water consumption associated with population growth in the countries of Central Asia are as follows: Uzbekistan—2596 m³/year/person, Turkmenistan— $4044 \mathrm{~m}^{3} /$ year/person, Tajikistan$1843 \mathrm{~m}^{3} /$ year/person, Kyrgyzstan-1371 m³/year/person, and Kazakhstan-1943 m³/year/person. Approximately 93.4 percent of the Amu Darya River water is used for irrigation [20,26]. Total draw-off from Amu Darya equals $61,500 \mathrm{~km}^{3} /$ year. The effectiveness of irrigation systems is about 50 percent $[20,21,24]$.

Many experts proposed different methods for overcoming the Aral Sea water crisis. Spoor [27] discussed the approaches to the efficient water management and sustainable land use in the Former Soviet Central Asia, when decisions were made centrally. In the post-Soviet era, decision making procedures are complicated and the political independence factor of five countries of Central Asia makes water resources allocation possible only through contracts in the framework of collaborative agreements. Micklin [11] analyzed the primary motivations, both climatic and economic, concerning the transfer of the flow of Northern European Rivers southward to Central Asia. Considering different nominally, practically realized projects, Micklin [12] made the conclusion that restoring average river inflow to the Aral Sea at about $56 \mathrm{~km}^{3} /$ year needs more than 100 years. Kostianou et al. [28] consider in detail the satellite monitoring possibilities to optimally manage water resources in Turkmenistan, at the zone where Kara-Bogaz-Gol and other important elements of the Aral Sea water cycle are located. It is evident that stabilization of the Central Asia water balance can be realized only by optimal control of existing water resources including the Amu Darya and Syr Darya Rivers. The solution of existing problems is usually realized by means of modeling tools [6,29]. A new method based on the modeling of the water balance of Central Asia and a scenario for its control is proposed in this paper.

\section{Method}

This paper proposes a new method for the solution of the Aral Sea water crisis and stopping its desiccation process through implementation of an evaporation/precipitation scenario (EPS), foreseeing weighed distribution of existing water resources of Central Asia. This method is based on the use of natural evaporators of Caspian water and rainmaking technology when evaporated moisture is delivered by the wind to the Aral Sea Basin and is artificially precipitated. Rainmaking technology is mainly used in agro-industrial sectors of the agrarian countries with droughty climate [30,31].

\subsection{Evaporation/Precipitation Scenario (EPS)}

The Aral Sea disappearance is visually demonstrated in Figure 1, where its satellite images are shown for 1960 and 2018. Historical data shows that the Aral Sea had stable levels fluctuating between 50 and $53 \mathrm{~m}$ during the last 200 years, prior to 1960 [9,32]. During this period, the Aral Sea surface was $51-61 \times 10^{3} \mathrm{~km}^{2}$ and its water balance was supported by Kara-Bogaz-Gol and the Amy Darya and Syr Darya rivers due to precipitation and river outflow [11,33]. Really, $50-60 \mathrm{~km}^{3} /$ year is evaporated from the Aral Sea surface, $9-10 \mathrm{~km}^{3} /$ year of water arrives with precipitation and $33-64 \mathrm{~km}^{3} /$ year is delivered 
with river inflow [34]. The hydrological history of some components of the Aral Sea Basin is shown in Table $1[3,12,32]$. A more detailed analysis of historical data shows that the Aral Sea level was changed by 2-3 $\mathrm{m}$ relatively, its absolute level of about $59 \mathrm{~m}$ above sea level. Hydro-meteorological conditions of Central Asia until 1960 provided enough stability to the Aral Sea level changes. After 1960, population growth in Central Asia republics of Former Soviet Union was the main cause of expansion of irrigation systems and construction of additional water reservoirs. During the next years after 1960, the irrigated area was increased by practically two times, from 4 billion ha to 8 billion ha. All these actions were realized at the expense of the Syr Darya and Amu Darya rivers. The first consequence of reduced river runoff to the Aral Sea was a decrease of its level by about $0.2 \mathrm{~m} /$ year from 1961 to 1970. The enormous situation with water use in Central Asia was continued in the 1970s, when only $17 \mathrm{~km}^{3} /$ year of river water was reaching the Aral Sea. The 1980s aggravated the situation. In this period, anthropogenic actions such as the construction of a dam between the Caspian Sea and Kara-Bogaz-Gol and the broadening of irrigation systems, gave only about $4 \mathrm{~km}^{3} /$ year of average water discharge $[35,36]$.

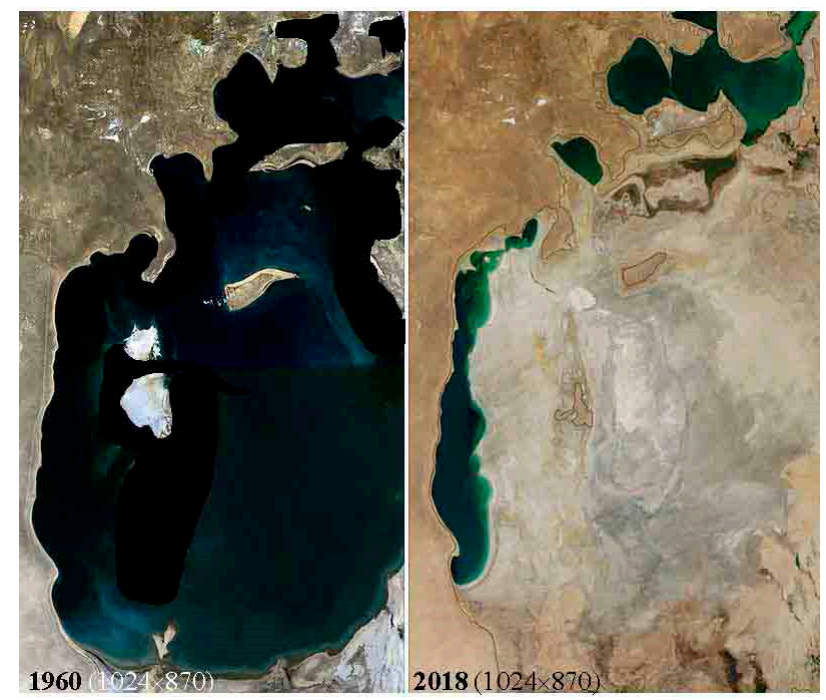

Figure 1. Aral Sea evolution history. Landsat satellite imagery mosaics showing visible changes of the Aral Sea. Source: USGS/NASA; visualization by UNEP/GRID-Sioux Falls. https://na.unep.net/geas/ getUNEPPageWithArticleIDScript.php?article_id=108.

Table 1. Hydrological history of the Aral Sea Basin (CAWATER Database of the Aral Sea. www.cawaterinfo.net>aral $>$ data $>$ index_e [12,17]).

\begin{tabular}{cccccccc}
\hline \multirow{2}{*}{ Year } & $\begin{array}{c}\text { Volume, } \\
\mathbf{k m}^{\mathbf{3}}\end{array}$ & $\begin{array}{c}\text { Area, } \\
\mathbf{k m}^{\mathbf{2}}\end{array}$ & $\begin{array}{c}\text { River Runoff to Aral Sea, } \mathbf{k m}^{\mathbf{3}} \\
\text { Amu Darya }\end{array}$ & $\begin{array}{c}\text { Syr Darya } \\
\text { Evaporation, }\end{array}$ & $\begin{array}{c}\text { Total } \\
\mathbf{k m}^{\mathbf{3}}\end{array}$ & $\begin{array}{c}\text { Precipitation, } \\
\mathbf{k m}^{\mathbf{3}}\end{array}$ \\
\hline 1960 & 1089 & 67,499 & 27.6 & 28.4 & 56.0 & 71.1 & 9.4 \\
\hline 1965 & 1030 & 63,900 & 0.6 & 0.3 & 0.9 & 66.1 & 7.8 \\
\hline 1970 & 927 & 60,198 & 0.4 & 0.2 & 0.6 & 54.3 & 4.3 \\
\hline 1975 & 762 & 55,900 & 0 & 0.2 & 0.7 & 57.7 & 4.9 \\
\hline 1980 & 670 & 52,400 & 0 & 1.2 & 1.2 & 38.5 & 7.1 \\
\hline 1985 & 468 & 44,398 & 0 & 0.3 & 0.3 & 47.9 & 3.5 \\
\hline 1990 & 364 & 36,400 & 3.1 & 3.1 & 3.1 & 35.3 & 5.3 \\
\hline 1995 & 287 & 33,497 & 0.4 & 1.6 & 4.7 & 28.5 & 2.5 \\
\hline 2000 & 183 & 24,100 & 3.0 & 2.7 & 3.5 & 23.1 & 4.2 \\
\hline 2005 & 110 & 19,000 & 2.0 & 4.4 & 7.4 & 14.0 & 3.5 \\
\hline 010 & 81 & 7143 & 2.0 & 2.5 & 4.5 & 11.4 & 3.0 \\
\hline 2015 & 48 & 6987 & 1.9 & 2.3 & 4.2 & 9.6 & 3.2 \\
\hline 2018 & 42 & 6348 & 2.1 & 2.4 & 4.5 & 9.7 & 3.3 \\
\hline
\end{tabular}


Certainly, the Aral Sea water balance depends on the Caspian Sea, the waters of which were earlier evaporated from the Kara-Bogaz-Gol $\left(\approx 6-12 \mathrm{~km}^{3} /\right.$ year) [37]. Anthropogenic impact on the regional water cycle started in 1980, when the blind dam was built between the Caspian Sea and Kara-Bogaz-Gol [38]. Eruption of the dam in 1992 did not stop the Aral Sea shoaling process. Chronology of the Aral Sea Basin events listed by Dukhovny and Sokolov [22] shows the existence of international concern about the competitive water saving program and solutions of the water resource conflict. Different predictions show the water deficit is increasing over the next several decades, due to global climate warming and a consequent decrease of glaciers in the Pamir-Alay system, as a main source of water resources in Central Asia [39].

- Thereby, understanding the Aral Sea evolution is possible through formal description of its hydrologic budget, taking into consideration the main water flows in the Central Asian region. Existing detailed descriptions of the water balance components in the Aral Sea Basin, as it was analyzed by Micklin [9], allow the realistic means for substantially increasing inflow to the Aral Sea Basin;

- Reducing the use of the Amy Darya and Syr Darya Rivers water for irrigation in the drainage basin;

- Elaboration and adoption of economic policies and emerging technologies for improvement and renovation of irrigation systems in all independent republics of Central Asia.

To realize this scenario, it is necessary to have a long-term collaborative agreement among the five countries of Central Asia and it would be preferable if Afghanistan became a party to such an agreement. In actuality, inflow of Syr Darya and Amu Darya water resources to the Aral Sea would only be increased to a negligible extent during the nearest decades. Therefore, additional means are proposed through implementation of the evaporation/precipitation scenario (EPS):

- Create the hydrologic system for the Caspian Sea water evaporation, through additional utilization of the Kara-Bogaz-Gol and natural evaporators-hollows located on the eastern coast of the Caspian Sea;

- Develop the simulation model of the Central Asia water cycle for the dynamic control of water flows and management of the evaporation processes;

- Use the rainmaking technology (i.e., cloud seeding with, for example, silver iodide) for the increase of precipitation above the Aral Sea.

Additional evaporators of the Caspian water could be deployed in numerous hollows such as, Kultuk (-27 m), Karagie (-132 m), Karyn-Zharyk (-75 m), Kaundy (-57 m), Kaidak (-31 m), Chagala Sor $(-30 \mathrm{~m})$, and Karin Arik $(-70 \mathrm{~m})$. These and other hollows on the eastern Caspian Sea coast are episodically flooded by rain waters, after the drying of which, salt marshes are formed. Artificially infilling these hollows with Caspian water could additionally result in approximately $90 \mathrm{~km}^{3} /$ year of evaporated water, that can partly arrive at the Aral Sea zone. Under this, the Kara-Bogaz-Gol, as a natural evaporator, having an area of about $18,000 \mathrm{~km}^{2}$, provides no less than $18.8 \mathrm{~km}^{3} /$ year of evaporated water, when $21.6 \pm 3.1 \mathrm{~km}^{3} /$ year is delivered to the Kara-Bogaz-Gol from the Caspian Sea. There exist other ideas as to how collected drainage waters could be delivered to the Aral Sea [17]. For example, water drainage waters can be collected in the Altyn Asyr Lake and can be forwarded to the Karashor Depression, located near the Sarykamysh Lake.

The Principal scheme of the EPS is represented in Figure 2, where numerous water flow studies were detailed and evaluated $[3,7-9,11,12,33,40]$. For example, basic flows, $E_{1}$ and $E_{6}$, are assessed as $370.1 \pm 19.3 \mathrm{~km}^{3} /$ year and $69.4 \pm 13.7 \mathrm{~km}^{3} /$ year, respectively. 


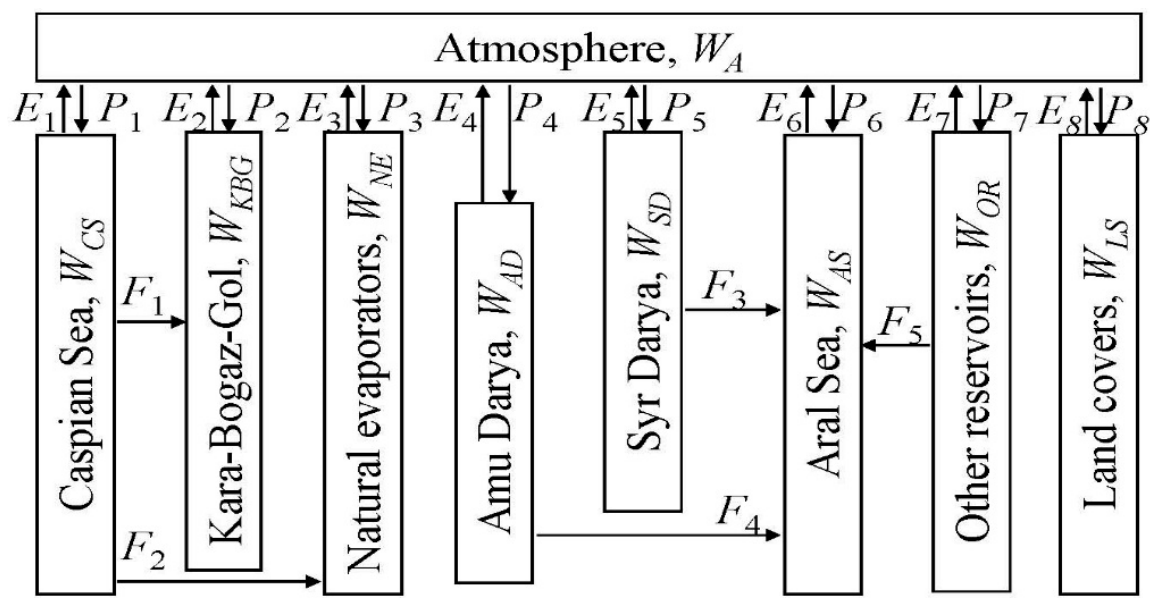

Figure 2. Principal block-scheme of main water cycle components in the Aral Sea zone.

Schematic representation of the water cycle of the Aral Sea zone can help to understand anomalous processes in this zone and to develop a sustainable strategy for this cycle control, taking into account earlier existing variations of the Caspian Sea level. Multiple satellite altimeter measurements deliver data pertinent to both the short term and decadal sea level variations, which would enable operative control of the EPS utilization and the fixation of the sea level trend.

Analysis of remote sensing data and of the peer-reviewed literature shows that the precipitation/evaporation relationship for the atmosphere/land cover system has a minor role in the water cycle of the Aral Sea Basin. Typical land cover includes grasslands, crops and deserts [41,42]. Detailed classification of the land covers was realized within remote sensing measurements, specifically with the flying radiometric laboratory IL-18(Iliushin-18) of the Kotelnikov Institute of Radioengineering and Electronics of the Russian Academy of Sciences [2,5,43]. The measurements were obtained with microwave radiometry at wavelengths $\mu=0.8,1.35,2.25,3.4,10,18,20,21,27$ and $30 \mathrm{~cm}$ [4]. Really, about $864,000 \mathrm{~km}^{2}$ of the Central Asia territory is sandy deserts. The total area covered with deserts of all types is 1,474,000 $\mathrm{km}^{2}(41.8 \%)$. Deserts of Central Asia have their maximum in precipitation during the winter months, when evaporation is minimal. Saxaul forests cover $60,000 \mathrm{~km}^{2}$ in Kazakhstan, $40,000 \mathrm{~km}^{2}$ in Turkmenistan and $20,000 \mathrm{~km}^{2}$ in Uzbekistan. Approximately $70 \%\left(2.8 \times 10^{6} \mathrm{~km}^{2}\right)$ of the total land area is classified as agricultural sector, including $2.5 \times 10^{6} \mathrm{~km}^{2}$ of rangelands and $0.3 \times 10 \mathrm{~km}^{2}$ of croplands. In common cases, relative air humidity is significantly differed above the land covers $(\approx 3 \%-6 \%)$ and water reservoirs $(\approx 42 \%-54 \%)$ [44].

The water losses from irrigation systems mainly divert to the ground waters or other reservoirs [23]. The largest consumers of Amu Darya and Syr Darya waters are Uzbekistan and Turkmenistan. Distribution of the country quotes for the water runoff of the Amu Darya and Syr Darya is as follows: Kazakhstan (0\%, 38.1\%), Kyrgystan $(0.4 \%, 1.0 \%)$, Tajikistan $(13.6 \%, 9.2 \%)$, Turkmenistan $43 \%$, 0\%) and Uzbekistan (43\%, 51.7\%). Non-optimal water utilization technologies, particularly in agriculture, have resulted in water losses that contribute to flooding and to the formation of new lakes. Remote sensing technologies enable operative control of these processes for their registration during long-term deployment of the EPS.

\subsection{Evaporation/Precipitation Model (EPM)}

The Aral Sea is functioning in the desert-continental climate under wide-ranging diurnal air temperatures, hot summers, cold winters, and sparse rainfall. Very small water sources exist for the revival of the sea. Really, the Amur Darya and Syr Darya, which earlier feed the Aral Sea, and precipitation are the primary water sources that could potentially revive the Aral Sea to its 1960 level [10]. The scheme in Figure 2 allows the balance equations for the main water cycle of Central Asia, so as to understand the extent of the devastation, to achieve partial rehabilitation of the Aral 
Sea, to advance towards regional hydrological sustainability and to maintain water security for the populations of the Central Asian countries. Negative changes in water volume of the Aral Sea can be neutralized in the framework of optimal management of the existing water resources. Before 1960, river runoff played an important role in the variations of the Aral Sea water volume. In this case, precipitation in the sea zone has no determinative importance. Taking anthropogenic factors into consideration, the role of precipitation is to be revised by means of the analysis of the main water balance equations that are basic for the evaporation/precipitation model (EPM):

$$
\begin{gathered}
\frac{\partial W_{A}(t, \varphi, \lambda)}{\partial t}+V_{\varphi} \frac{\partial W_{A}(t, \varphi, \lambda)}{\partial \varphi}+V_{\lambda} \frac{\partial W_{A}(t, \varphi, \lambda)}{\partial \lambda}=r_{C}\left(E_{1}-P_{1}\right)+\sum_{i=2}^{8}\left(E_{i}-P_{i}\right) \\
\frac{\partial W_{A S}(t)}{\partial t}=F_{3}+F_{4}+F_{5}+P_{6}-E_{6}
\end{gathered}
$$

where, $r_{C}$ is the correction coefficient $(\approx 0.065)$ reflecting the role of the Caspian Sea in the water balance of the Aral Sea, $\phi$ and $\lambda$ are geographical coordinates $(\phi, \lambda) \in \Xi=\left(40^{\circ}, 47^{\circ}\right) \cup\left(52^{\circ}, 63^{\circ}\right)$, and $V=\left(V_{\phi}, V_{\lambda}\right)$ is the wind speed $\left(\mathrm{km} /\right.$ day). Coefficient $r_{C}$ is calculated based on the minimal difference of modeling results from observed Aral Sea volumes.

Balance equations for other water reservoirs have an analogous view, as in Equation (2). A computer realization of these equations is based on the division of the study area $\Xi$ into discrete spatial elements (pixels) $\Xi_{i j}$ with area $\sigma=\Delta \phi \times \Delta \lambda\left(\mathrm{km}^{2}\right)$. The water flows in Figure 2 are described by the analytical, table and graphical functions $[4,16,43,45,46]$. A reconstruction of the sea surface area $\sigma_{A S}$ is realized by means of empirical equation:

$$
\sigma_{A S}=q_{1} W_{A S}-q_{2} W_{A S}^{2}\left(\mathrm{~km}^{2}\right)
$$

where, $W_{A S}$ is the sea volume $\left(\mathrm{km}^{3}\right), q_{1}=137.84(\mathrm{~km})$ and $q_{2}=0.0719\left(\mathrm{~km}^{-1 / 2}\right)$.

The rainfall, $P_{6}$, depends on the water flow, $r_{C} E_{1}+E_{2}+E_{3}$, that is a function of temperature and is stochastically changed during the year under the effects of the wind direction. Wind regime of the Aral Sea region is characterized by the recurrence of the north-east directions $(\approx 30 \%)$. Integrally, the isobars are oriented from the north-east to the south-west during summer and from the north-west to the north-east during winter. A wind rise of the Aral Sea is formed depending on the climatic factors of Central Asia, where sand deserts play the main role. The Average wind speed was 4-6 m/s in the Caspian coastal zone with variations about $2 \mathrm{~m} / \mathrm{s}$, and it can reach $34-36 \mathrm{~m} / \mathrm{s}$ in pre-mountain plains [47-49]. Figure 3 shows average wind raises for the Aral Sea region. Finally, Gaybullaev et al. [3] showed that precipitations, $P_{6}$, in the Aral Sea zone during the last decades slowly and certainly fall with the following law:

$$
P_{6}=213.25-0.1047 t
$$

where, $t$ is the current year between 1956 and 2015. After 2015, precipitations are varied in the range of $2.2-2.4 \mathrm{~km}^{3} /$ year.

As it was observed, values of the evaporation, $E_{2}$, from Kara-Bogaz-Gol and precipitation, $P_{6}$, on Aral Sea area are subjected to the following dependency:

$$
P_{6}=0.000972 E_{2}^{2}-0.464 E_{2}+56.981
$$

Dependencies (4) and (5) show that precipitations above the Aral Sea are falling and are occurring minimally during summer when evaporation from the Caspian Sea and Kara-Bogaz-Gol is maximal. This fact verifies the EPS algorithm for the increase of precipitations in the Aral Sea Basin involving 
additional evaporators of Caspian water and rainmaking technology. Dynamics of the Aral Sea water volume are described by the following equation:

$$
W_{A S}(t+\Delta t)=W_{A S}(t)+\left[P_{6}(t)+F_{3}(t)+F_{4}+F_{5}(t)-E_{6}(t)\right] \Delta t
$$

\section{Results and Discussion}

Drastic changes of the water cycle in Central Asia after known anthropogenic actions seem impassable under existing economical and political systems taking place in five independent republics. Further, the Aral Sea ecosystem degradation will result in further deterioration of the human population's living conditions. Realization of the EPS necessitates their cooperation, including that of Iran. The EPM allows the evaluation of the EPS realization to partially restore the sea's hydrology along with its area stability. It is supposed that current and future climatic trends in the Aral Sea region conform to global climate change [18]. Wind fields in this region are represented in Figure $3[1,47,50]$.

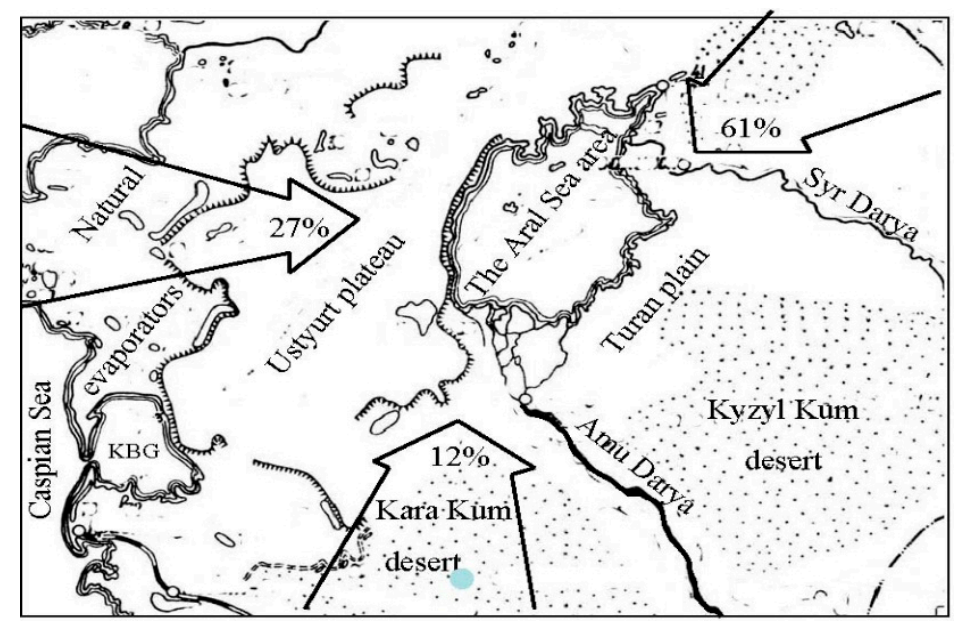

Figure 3. Prevailing wind directions in the Aral Sea zone and their recurrence [47,51].

Simulation experiments are realized for spatial resolution $\Delta \phi=\Delta \lambda=1 / 6^{\circ}$ and temporal scale $\Delta t=1$ day. Equations (1) and (2) are digitized according to these parameters. Boundary conditions for balance equations are evaluated on the base of existing meteorological and satellite data of Central Asia $[28,38,49,52]$. The starting time for the EPS realization is $t_{0}=2020$ when, $W_{C S}=78,200,000 \mathrm{~km}^{3}$, $W_{K B G}=15 \mathrm{~km}^{3}, W_{N E}=75 \mathrm{~km}^{3}, W_{S D}=38 \mathrm{~km}^{3}, W_{A D}=79 \mathrm{~km}^{3}, W_{A S}=42.6 \mathrm{~km}^{3}, W_{O R}=150 \mathrm{~km}^{3}$, and $W_{L S}=0.00011 \mathrm{~km}^{3}$.

It is accepted that evaporation/precipitation relations for principal water sources to the atmosphere humidity are fluctuated no more than $5 \%$ during the next decades and have average assessments, as represented in Table 2. As it was shown by in-situ and remote sensing measurements, the land cover elements play a slight role in comparison with reservoirs in the water balance of Central Asia $[4,53,54]$. Land surface plays a certain role in the heavily populated areas where agricultural vegetation is prevailing. Total database of land covers in Central Asia was synthesized in a framework of remote sensing measurements by means of flying laboratory IL-18 of the Former Soviet Union [5,55]. This laboratory was equipped by the radio-locators with synthetic aperture, microwave radiometers of different wavelengths, gravimetric and inertial devices, large-format and frame TV, aero-camera and other complementary devices. The land covers and reservoirs are classified with spatial resolution of 200-500 m, depending on the region. 
Table 2. Principal elements of the Aral Sea water balance. Notation: $\sigma_{C S}=371,000 \mathrm{~km}^{2}, \sigma_{K B G}=18,000$ $\mathrm{km}^{2}, \sigma_{O R}=21,400 \mathrm{~km}^{2}, \sigma_{N E}=70,000 \mathrm{~km}^{2}$.

\begin{tabular}{|c|c|c|c|c|c|c|c|c|}
\hline \multirow{2}{*}{ Month } & \multicolumn{4}{|c|}{ Evaporation, $\mathrm{mm} / \mathrm{month}$} & \multicolumn{4}{|c|}{ Precipitation, $\mathrm{mm} / \mathrm{month}$} \\
\hline & $E_{1} / \sigma_{C S}$ & $E_{2} / \sigma_{K B G}$ & $E_{6} / \sigma_{N E}$ & $E_{7} / \sigma_{O R}$ & $P_{1} / \sigma_{C S}$ & $P_{2} / \sigma_{K B G}$ & $P_{6} / \sigma_{N E}$ & $P_{7} / \sigma_{O R}$ \\
\hline I & 59 & 81 & 83 & 56 & 122 & 15 & 14 & 12 \\
\hline II & 58 & 88 & 91 & 61 & 97 & 13 & 12 & 10 \\
\hline III & 61 & 99 & 103 & 72 & 60 & 8 & 8 & 6 \\
\hline $1 \mathrm{~V}$ & 64 & 112 & 118 & 88 & 66 & 9 & 9 & 7 \\
\hline $\mathrm{V}$ & 67 & 139 & 142 & 103 & 71 & 10 & 9 & 9 \\
\hline VI & 89 & 204 & 211 & 126 & 102 & 13 & 11 & 10 \\
\hline VII & 106 & 206 & 212 & 134 & 116 & 15 & 13 & 12 \\
\hline VII & 103 & 211 & 210 & 127 & 129 & 17 & 16 & 13 \\
\hline IX & 68 & 141 & 144 & 105 & 158 & 21 & 19 & 16 \\
\hline$X$ & 60 & 129 & 133 & 93 & 269 & 35 & 34 & 17 \\
\hline XI & 58 & 103 & 105 & 71 & 175 & 23 & 23 & 15 \\
\hline XII & 52 & 91 & 94 & 57 & 124 & 16 & 15 & 13 \\
\hline
\end{tabular}

Practically, water evaporated from agricultural irrigable areas does not arrive at the Aral Sea zone because of the wind rise. Therefore, simulation experiments show that atmosphere/land surface water balance outside irrigable areas is practically neutral.

The following EPS versions are considered:

- EPS-1: Only Kara-Bogaz Gol is used as a natural evaporator.

- EPS-2: Kara-Bogaz Gol and other natural evaporators are used.

- EPS-3: In addition to EPS-2, the river water diversion is decreased by $5 \%$ and rainmaking technology is used.

- EPS-4: In addition to EPS-2, the river water diversion is decreased by $10 \%$ and rainmaking technology is used.

The precision of simulation results is mainly defined by the climate scenario. Existing scenarios of global climate change propose a wide range of average global temperature change. This problem and its connected discussions are not considered here. Following from Krapivin et al. [5], the next climate change in the Central Asia scenario is accepted. Three climatic zones are marked out: mid-latitude desert, steppe and humid continental. During the last years from 1960, climate change in these zones has increased average annual temperatures in the range from $0.1^{\circ} \mathrm{C}$ to $1.1^{\circ} \mathrm{C}$. It is supposed that this trend in change of the average annual temperature is preserved until 2150.

Finally, simulation results are given in Tables 3 and 4, which show hydrological elements of the Aral Sea Basin in their dynamics after the EPS-4 realization. These results demonstrate the existence of an effective strategy for the management of the Central Asia water resources using the EPM manipulations and tools for the big data processing [56].

Certainly, use of the EPS-4 has numerous restrictions and uncertainties. Nevertheless, 10 percent of river flow return is really realized taking into consideration that water losses in irrigation systems of Central Asia are about 50 percent. A quota of 10 percent equals $4.5 \pm 0.2 \mathrm{~km}^{3} /$ year. Water losses from irrigation systems lead to waterlogging and an increase of the level of ground waters. During the last two decades, the level of ground waters was increased from $3 \mathrm{~m}$ to $1.2-1.5 \mathrm{~m}$ in many regions of Central Asia $[12,35]$. 
Table 3. Recovery chronology of the Aral Sea volume when the Evaporation/Precipitation Scenarios (EPS's) are realized.

\begin{tabular}{ccccc}
\hline \multirow{2}{*}{ Years after Beginning the EPS Realization } & \multicolumn{4}{c}{ Aral Sea Volume, $\mathbf{~ k m}^{\mathbf{3}}$} \\
\cline { 2 - 5 } & EPS-1 & EPS-2 & EPS-3 & EPS-4 \\
\hline 0 & 42.6 & 42.6 & 42.6 & 42.6 \\
\hline 15 & 78.3 & 117.8 & 171.2 & 209.1 \\
\hline 30 & 82.4 & 208.9 & 339.3 & 430.9 \\
\hline 60 & 131.8 & 377.8 & 664.1 & 1015.4 \\
\hline 70 & 157.6 & 443.5 & 755.3 & 1041.1 \\
\hline 80 & 169.9 & 457.6 & 846.2 & 1054.3 \\
\hline 90 & 183.4 & 521.6 & 859.5 & 1068.8 \\
\hline 100 & 209.7 & 651.4 & 976.3 & 1069.2 \\
\hline 120 & 235.7 & 780.9 & 1041.7 & 1077.4 \\
\hline 150 & 287.8 & 784.6 & 1042.8 & 1079.8 \\
\hline
\end{tabular}

Table 4. The Aral Sea recovery dynamics depending on the area of natural evaporators. Notation: (1) EPS-2 is used and rainmaking with $90 \%$ efficiency, (2) EPS-3 is used with the rainmaking efficiency $90 \%$, (3) EPS-4 is used with rainmaking efficiency $60 \%$, (4) EPS-4 is used with rainmaking efficiency $90 \%$.

\begin{tabular}{ccccc}
\hline \multirow{2}{*}{ Area of Evaporators, $\mathbf{k m}^{\mathbf{2}}$} & \multicolumn{5}{c}{ Years of the Aral Sea Recovery } \\
\cline { 2 - 5 } & $\mathbf{( 1 )}$ & $\mathbf{( 2 )}$ & $\mathbf{( 3 )}$ & $\mathbf{( 4 )}$ \\
\hline 20,000 & 318 & 243 & 205 & 169 \\
\hline 30,000 & 273 & 210 & 162 & 148 \\
\hline 40,000 & 242 & 173 & 144 & 125 \\
\hline 50,000 & 222 & 147 & 123 & 117 \\
\hline 60,000 & 207 & 128 & 118 & 104 \\
\hline 70,000 & 194 & 119 & 109 & 97 \\
\hline 80,000 & 183 & 113 & 104 & 95 \\
\hline 90,000 & 181 & 102 & 96 & 92 \\
\hline
\end{tabular}

Existing separate data shows that the Aral Sea area had been reduced to $78 \%$ of its 1960 size and water volume had decreased by about $90 \%$. The most dangerous situation is formed in Central Asia, due to the increased salinity, by more than 12 times the salinity of sea water, which negatively impacts the fishery industry. The salinity of the Aral Sea increased from $10 \mathrm{~g} / \mathrm{L}$ to $135 \mathrm{~g} / \mathrm{L}$, depending on separated basins of the Aral Sea [11]. The Aral Sea prior to its modern desiccation had an average salinity around $10 \mathrm{~g} / \mathrm{L}$. As a result, the Aral Sea degradation leads to socio-economic and public health problems, taking into account increased sand-storms and desertification [36]. Present-day processes of free salts migration cause negative consequences for agriculture within the Central Asian countries. Remote sensing tools, such as the IL-18 laboratory, can provide regular monitoring of land covers with the assessments of their characteristics and delivering reliable information for decision making offices.

Realization of the EPS-4 gives perspective to partly restore the Aral Sea within this century. Detailed analysis of simulation experiments allows the assessment of different components of the Central Asia water cycle and the understanding of the role of each country in water cycle stabilization. As it follows from Tables 3 and 4, the Aral Sea recovery can be realized under conditions which are to be acceptable for all countries of Central Asia.

The recovery scenario proposed and partly analyzed in this paper opens the perspective to identify a solution to the Aral Sea problem and to overcome the existing contradictions between the 
governments of Central Asia concerning optimal and equitable management of water resources. Many experts propose different views on this problem-from optimistic to pessimistic [1,3,35]. An optimistic project is realized in Kazakhstan by means of Amu Darya riverbed management [9].

In actuality, existing runoff of Amy Darya and Syr Darya to the Aral Sea is assessed by $\approx 11-13 \mathrm{~km}^{3} /$ year when $43-47 \mathrm{~km}^{3}$ of river waters are taken away for irrigation (92\%), industry $(4.3 \%)$ and population use (4.4\%). The EPS-4 provides for the increase of up to $20 \mathrm{~km}^{3} /$ year of river runoff to the Aral Sea, together with additional evaporation of the Caspian water and deployment of rainmaking technology, such as cloud seeding with, for example, silver iodide, potassium iodide, frozen carbon dioxide, or liquid propane. In this case, precipitation in the Aral Sea Basin can potentially increase to $\approx 1500-2000 \mathrm{~mm} /$ year, depending on the climatic situation under evaporation of $\approx 900-1000 \mathrm{~mm} /$ year. The result of the EPS- 4 utilization is a function of many uncertain environmental conditions, such as climate change, strategies of the independent republics in the water use, population growth and the river runoffs to the Caspian Sea.

The Aral Sea crisis is to be solved at the expense of a complex approach to the sustainable development of the Central Asian region, taking into consideration an array of scientific, social and ecological aspects. It is evident that the following actions are to be initiated:

- Reconstruction of existing old irrigation systems;

- Development and introduction of effective irrigation technologies such as drip irrigation;

- Reconstruction of municipal water supply systems, and

- Optimization of the drainage runoffs.

Preliminary analysis of the Central Asia water cycle shows that there exist reserves for the improvement of the ecological situation and for ultimate initiation of the Aral Sea recovery process. Existing reservoirs such as Sarykamysh Lake $\left(\approx 5000 \mathrm{~km}^{2}\right)$, geographically located between the Caspian Sea and the Aral Sea, can be water sources for the Aral Sea. Lake Balkhash $\left(16,400 \mathrm{~km}^{2}\right)$ can also be considered as an important element of the Aral Sea water balance. Certainly, realization of these actions requires the adequate capital investments and scientific efforts to optimize this process. Principally, global ecoinformatics proposes tools for the solution of such environmental tasks [5,16,57-59]. Realization of the EPS-4 is possible in the framework of the UN Program, when it is possible to focus scientific efforts on the synthesis of global water cycle models, in the framework of which EPM can be used as a sub-block. In this case, the optimal strategy for Central Asia water balance can be defined and realistic monitoring procedures can be identified. Only in this case, social and economic stresses existing in practically all countries of Central Asia will find a solution and human vulnerability will be reduced. Undoubtedly, reliability of these results depends on regional climate change scenarios [18]. Therefore, it will be created in such a manner that information-modeling technology would combine operative monitoring data with the water balance model and with assumptions of timely decision making, to correct regional changes in the agricultural and social strategies.

Certainly, the reliability level of modeling results is an important aspect of the results shown in Tables 3 and 4. Table 5 gives some characteristics for the EPM precision level. Average deviation of the EPM results from the observed volume of the Aral Sea equals 8.3\%. The EPM precision can be considered as consistent with the reliable description of the Aral Sea hydrological regime. As it follows from Table 5, the EPM can be considered as a tool for primary assessment of different scenarios for the Aral Sea water balance management. It is evident that practical EPM use needs additional development. 
Table 5. Comparison of observed and calculated Aral Sea levels [3,35,60]. EPM = Evaporation/ Precipitation Model.

\begin{tabular}{|c|c|c|c|c|c|}
\hline \multirow{2}{*}{ Year } & \multicolumn{2}{|c|}{ Aral Sea Volume, km ${ }^{3}$} & \multirow{2}{*}{$\begin{array}{l}\text { EPM } \\
\text { Error, \% }\end{array}$} & \multicolumn{2}{|c|}{ Historical Data Used in EPM } \\
\hline & $\begin{array}{l}\text { River Runoff to Aral } \\
\text { Sea, } \mathrm{km}^{3} / \text { year }\end{array}$ & $\begin{array}{l}\text { Caspian Water Flow to } \\
\text { Kara-Bogaz-Gol, } \mathrm{km}^{3} / \text { year }\end{array}$ & & Observed & Calculated \\
\hline 1957 & 1080.0 & 1080.0 & 0 & 19.4 & 21.8 \\
\hline 1960 & 1089.0 & 1067.9 & 2 & 42.0 & 24.2 \\
\hline 1965 & 1030.1 & 999.2 & 3 & 0.3 & 20.3 \\
\hline 1970 & 927.3 & 1010.4 & 9 & 0.2 & 15.2 \\
\hline 1973 & 824.2 & 947.6 & 15 & 0.9 & 10.6 \\
\hline 1975 & 762.4 & 846.3 & 11 & 0.2 & 12.2 \\
\hline 1977 & 749.2 & 839.1 & 12 & 0.2 & 7.1 \\
\hline 1980 & 670.4 & 603.4 & 10 & 1.2 & 1.2 \\
\hline 1982 & 579.8 & 533.4 & 8 & 1.3 & 0 \\
\hline 1984 & 502.7 & 457.5 & 9 & 0.3 & 2.4 \\
\hline 1985 & 468.3 & 505.8 & 8 & 0.3 & 4.9 \\
\hline 1987 & 345.6 & 383.6 & 11 & 1.0 & 6.8 \\
\hline 1989 & 327.2 & 363.2 & 11 & 3.1 & 9.6 \\
\hline 1990 & 304.1 & 337.6 & 9 & 3.1 & 13.0 \\
\hline 1992 & 290.5 & 255.6 & 12 & 10.6 & 16.4 \\
\hline 1995 & 239.0 & 262.9 & 10 & 4.7 & 22.5 \\
\hline 1996 & 217.4 & 236.9 & 9 & 6.6 & 25.2 \\
\hline 1998 & 182.9 & 195.7 & 7 & 31.5 & 28.9 \\
\hline 2000 & 195.4 & 218.8 & 12 & 9.7 & 17.7 \\
\hline 2001 & 149.1 & 193.8 & 13 & 3.1 & 16.4 \\
\hline 2002 & 129.2 & 118.9 & 8 & 13.1 & 12.5 \\
\hline 2003 & 117.0 & 125.2 & 7 & 20.6 & 15.4 \\
\hline 2004 & 110.9 & 118.7 & 7 & 15.8 & 24.3 \\
\hline 2005 & 112.3 & 105.6 & 6 & 7.4 & 25.2 \\
\hline 2006 & 105.3 & 96.9 & 8 & 5.0 & 20.6 \\
\hline 2007 & 104.3 & 114.6 & 7 & 7.0 & 23.7 \\
\hline 2008 & 103.1 & 93.8 & 9 & 6.1 & 22.9 \\
\hline 2009 & 102.0 & 109.1 & 7 & 5.2 & 21.6 \\
\hline 2010 & 98.1 & 105.9 & 8 & 4.5 & 20.8 \\
\hline 2015 & 48.3 & 52.6 & 6 & 2.3 & 19.3 \\
\hline 2018 & 42.2 & 46.0 & 9 & 2.4 & 22.1 \\
\hline
\end{tabular}

The results of Table 3 show that separated water bodies of the Aral Sea, existing at the present time, will be merged after 35-40 years of EPS-4 realization. It shows that a principal solution of the Aral Sea problem exists, and its volume of the 1960's can be reached during visible time. Versions of the Evaporation/Precipitation Scenario, considered here, will help to form the recovery strategy [6,12].

Overcoming the Aral Sea crisis needs preliminary solutions of socio-economic problems existing in Central Asia, which at the present time is a barrier for the constructive consideration of alternative plans. Many publications propose different methods to search for the solution to the Central Asia water problem, including scenarios and models [5,6,16,42,51]. It is evident that the Aral Sea does not exist in isolation from the Caspian and Black Seas, and the Don and Volga Rivers. Therefore, these 
water resources are to be taken into consideration under the improvement of the method considered in this paper.

\section{Conclusions}

Water resources play a key role in the economies of the five Central Asian countries. The Central Asia Climate Change Conference in partnership with the World Bank (24-25 January 2018, Almaty, Kazakhstan) again poses the question, "what is the extent of the water crisis in Central Asia and what are the possible solutions for the communities living in those areas?" The answer to which is possible with the attraction and development of new information-modeling technologies [5,40]. This paper proposes one of the possible approaches to this purpose.

The mathematical model of Equations (1)-(6) takes into account the different elements of the Central Asia water cycle, including glaciers, rivers and Caspian Sea water flow to the Kara-Bogaz-Gol. Simulation results represented in this paper provide a platform for the discussion of possible approaches to the solution of Central Asia water problems. It is evident that the Aral Sea crisis is a local problem of Central Asia. The hydrological restoration of the Aral Sea to a previous higher water level can be realized by means of coupled consideration of the Central Asia water cycle model and a global climate model. Undoubtedly, any global climate model needs additional information and, as a rule, needs to introduce elements of information uncertainties and instabilities. Therefore, this study uses a simple climate model by Mintzer [61] that reduces a considerable uncertainty.

The governments of Central Asia have begun to intensively discuss a possible joint program for the revision of existing strategies for the optimization of the restricted water resources. A perfection of the water control technologies can be realized by means of using existing information-modeling tools [5]. Using the Equations (1)-(6) model simulations shows that a principal solution for the Aral Sea problem exists. The model verification is realized by a comparison of historical data about the Aral Sea volume dynamics and modeling results during 1957-2018, which shows that the model error is no more 15 percent (see Table 5), depending on the variations of the historical data. Certainly, this precision can be improved when the EPM is used together with more detailed descriptions of topographic and ecological parameters of the Aral Sea Basin. It can be realized in the framework of the UN initiative on overcoming the water crisis in Central Asia [62].

Author Contributions: V.F.K. and F.A.M. designed the hydrological model and performed the numerical simulations. G.L.R. realized the analysis and review of literature sources and prepared data for the simulation experiments. V.F.K. wrote the article with support from F.A.M. and G.L.R.

Funding: Authors thank Russian Fund for Basic Research for spending support of the work, «Project RFBR № 19-07-00443-a».

Conflicts of Interest: The authors declare no conflict of interest. The funders had no role in the design of the study; in the collection, analyses, or interpretation of data; in the writing of the manuscript, or in the decision to publish the results.

\section{References}

1. Aladin, N.V.; Chlebovich, V.V. (Eds.) Hydrobiological Problems of the Aral Sea; Zoological Institute Publishing: Leningrad, Russia, 1989; p. 145. (In Russian)

2. Borodin, L.F.; Krapivin, V.F.; Long, B.T. Application of the GIMS technology to the Aral-Caspian aquageosystem monitoring. Probl. Environ. Nat. Resour. 1996, 10, 46-61. (In Russian)

3. Gaybullaev, B.; Chen, S.-C.; Gaybullaev, G. Changes in water volume of the Aral Sea after 1960. Appl. Water Sci. 2012, 2, 285-291. [CrossRef]

4. Krapivin, V.F.; Shutko, A.M.; Chukhlantsev, A.A.; Golovachev, S.P. Simulation system for investigation of the Aral-Caspian water regime. J. Terr. Obs. 2008, 1, 60-69.

5. Krapivin, V.F.; Varotsos, C.A.; Soldatov, V.Y. New Ecoinformatics Tools in Environmental Science: Applications and Decision-Making; Springer: London, UK, 2015; p. 903. 
6. Krapivin, V.F.; Nitu, C.; Varotsos, C.A. Remote Sensing Tools and Ecoinformatics; Matrix Rom: Bucharest, Romania, 2019; p. 332.

7. Micklin, P.P. The fato 'Siberial': Soviet water politics in the Gorbachev era. J. Cent. As. Sur. 1987, 6, 67-88. [CrossRef]

8. Micklin, P.P. Desiccation of the Aral Sea: A Water Management Disaster in the Soviet Union. Science 1988, 241, 1170-1176. [CrossRef]

9. Micklin, P.P. The Aral Sea disaster. Annu. Rev. Earth Planet. Sci. 2007, 35, 47-72. [CrossRef]

10. Micklin, P.P. Efforts to revieve the Aral Sea. In The Aral Sea: The Devastation and Partial Rehabilitation of a Great Lake; Micklin, P.P., Aladin, N.V., Plotnikov, I., Eds.; Springer: Berlin, Germany, 2014; pp. 361-380.

11. Micklin, P.P. The Siberian water transfer scheme, Chapter 16. In The Aral Sea; Micklin, P.P., Aladin, N.V., Plotnikov, I., Eds.; Springer: Berlin/Heidelberg, Germany, 2014; pp. 381-404.

12. Micklin, P.P. The future Aral Sea: Hope and despair. Environ. Earth Sci. 2016, 75, 1-15. [CrossRef]

13. Ashirbekov, U.A.; Zonn, I.S. The History of Drying Sea; Executive Committee of International Fund for Saving the Aral Sea: Dushanbe, Tajikistan, 2003; p. 86.

14. Hublaryan, M.G. The Caspian Sea phenomenon. Her. Rus. Acad. Sci. 1995, 65, 616-630. (In Russian)

15. Pearce, F. How the soviet seas were lost. New Sci. Lond. 1995, 148, 38-42.

16. Rochon, G.L.; Krapivin, V.F.; Mkrtchyan, F.A. Symulation system to study the Aral-Caspian water regime. In Proceedings of the IX International Symposium, Engineering Ecology, Moscow, Russia, 5-7 December 2017; pp. 99-104.

17. Zonn, I.S.; Kostianoy, A.G. (Eds.) The Turkmen Lake Altyn Asyr. In The Turkmen Lake Altyn Asyr and Water Resources in Turkmenistan; Springer: Berlin, Germany, 2013; pp. 197-231.

18. Lioubimtseva, E. Impact of climate change on the Aral Sea and its basin. In The Aral Sea. The Devastation and Partial Rehabilitation of a Great Lake; Micklin, P., Aladin, N.V., Plotnikov, I., Eds.; Springer: Berlin, Germany, 2014; pp. 405-427.

19. Panin, G. Caspian Sea level fluctuations as a consequence of regional climatic change. In Global Change: Enough Water for all? Lozán, J.L., Grassl, H., Hupfer, P., Menzel, L., Schönwiese, C.-D., Eds.; Wissenschaftliche Auswertungen: Hamburg, Germany, 2007; pp. 216-219.

20. Rizk, J.; Utemuratov, B. Balancing the Use of Water Resources in the Amu Darya Basin; An East West Institute: Brussels, Belgium, 2012; p. 21.

21. Suleimenova, Z. Water Security in Central Asia and the Caucasus-A Key to Peace and Sustainable; MPFD Working Papers, ESCAP: Bangkok, Thailand, 2018; pp. 1-28.

22. Dukhovny, V.; Sokolov, V. Lessons on Cooperation Building to Manage Water Conflicts in the Aral Sea Basin; UNESCO: London, UK, 2003; p. 50.

23. Izquierdo, L.M.; Stangerhaugen, M.; Castillo, D.; Nixon, R.; Jimenez, G. Water Crisis in Central Asia: Key Challenges and Opportunities; Graduate Program in International Affairs, New School University: New York, NY, USA, 2010; p. 64.

24. Valentini, K.L.; Orolbaev, E.E.; Abylgazieva, A.K. Water Problems of Central Asia; International Strategic Research Institute: Bishkek, Kyrgyzstan, 2004; p. 142.

25. Glantz, M. Water, climate, and development issues in the Amu Darya basin. Mitig. Adapt. Strateg. Global Change 2005, 10, 23-50. [CrossRef]

26. Ibrahinzada, M.W.; Sharma, D. Vulnerability assessment of water resources in Amu Darya river basin, Afganistan. Int. J. Environ. Sci. 2012, 2, 802-812.

27. Spoor, M. The Aral Sea Basin crisis: Transition and environment in Former Soviet Central Asia. Dev. Change 1998, 29, 409-435. [CrossRef]

28. Kostianoy, A.G.; Lebedev, S.A.; Solovyov, D.M. Satellite Monitoring of the Caspian Sea, Kara-Bogaz-Gol Bay, Sarykamysh and Altyn Asyr Lakes, and Amu Darya River. In The Turkmen Lake Altyn Asyr and Water Resources in Turkmenistan; Zonn, I.S., Kostianoy, A.G., Eds.; Springer: London, UK, 2014; pp. 197-231.

29. Sabitov, T.; Murphy, C.B.; Quackenbush, L.J. Hydrologic Modeling of Glaciated Watershed in Central Asia; Elsevier: Amsterdam, The Netherlands, 2018; p. 56.

30. Chumchean, S.; Bunthai, W. Testing efficacy of rainmaking activities in the northeast of Thailand. In Proceedings of the 10th WMO Scientific Conference on Weather Modification, Bali, Indonesia, 4-6 October 2011; pp. 185-188. 
31. Chumchean, S.; Hanchoowong, R.; Bunthai, W. Comparison between rainmaking and natural rainfall in the northeastern part of Thailand. In Proceedings of the 5th APHW Conference, Hanoi, Vietnam, 8-10 November 2010.

32. Breckle, S.-W.; Geldyeva, G.V. Dynamics of the Aral Sea in Geological and Historical Times. In Landscape Dynamics in the Southern Aralkum: Using MODIS Time Series for Land Cover Change Analysis; Löw, F., Navratil, P., Bubenzer, O., Eds.; Springer: Berlin, Germany, 2012; pp. 13-35.

33. Micklin, P.; Aladin, N.V.; Plotnikov, I. (Eds.) The Aral Sea: The Devastation and Partial Rehabilitation of a Great Lake; Springer: Chichester, UK, 2014; p. 453.

34. Gaybullaev, B.; Chen, S.-C.; Gaybullaev, G. The large Aral Sea water balance: A future prospective of a large Aral Sea depending on water volume alteration. Carbonates Evaporites 2014, 29, 211-219. [CrossRef]

35. Cretaux, J.-F.; Letolle, R.; Bergé-Nguyen, M. History of Aral Sea level variability and current scientific debates. Glob. Planet. Chang. 2013, 110, 99-113. [CrossRef]

36. Gaybullaev, B.; Kuo, Y.-M. Large-scale desiccation of the Aral Sea due to over-exploitation after 1960. J. Mt. Sci. 2012, 9, 538-546. [CrossRef]

37. Catchcart, R.B.; Badescu, V. Aral Sea partial refill with imported Caspian Sea water. In Engineering Earth; Brunn, S.D., Ed.; Springer: Berlin, Germany, 2011; pp. 1541-1547.

38. Gippius, F.; Arkhipkin, V.S.; Frolov, A.V. Seasonal variations of evaporation from the Caspian Sea surface with account of wind waves and sea depth. Mosc. Univ. Bull. Geogr. 2016, 5, 86-92. (In Russian)

39. Aisen, V. Pamir glaciers. In Encyclopedia of Snow, Ice and Glaciers; Sigh, V.P., Singh, P., Eds.; Springer: London, UK, 2011; pp. 1253-1257.

40. Kondratyev, K.Y.; Krapivin, V.F.; Varotsos, C.A. Natural Disasters as Interactive Components of Global Ecodynamics; Springer: Chichester, UK, 2006; p. 578.

41. Klein, I.; Gessner, U.; Kuenzer, C. Generation of up to date land cover maps for Central Asia. In Novel Measurement and Assessment Tools for Monitoring and Management of Land and Water Resources in Agricultural Landscapes of Central Asia; Mueller, L., Saparov, A., Lischeid, G., Eds.; Springer: London, UK, 2014; pp. 329-346.

42. Small, E.E.; Sloan, L.C. Simulating the water balance of the Aral Sea with a coupled regional climate-lake model. J. Geophys. Res. 1999, 104, 6583-6602. [CrossRef]

43. Krapivin, V.F.; Phillips, G.W. A remote-sensing based expert system to study the Aral-Caspian aquageosystem water regime. Remote Sens. Environ. 2001, 75, 201-215. [CrossRef]

44. Vogtmann, H.; Dobretsov, N. (Eds.) Environmental Security and Sustainable Land Use-With Special Reference to Central Asia; Springer: Amsterdam, The Netherlands, 2006; p. 380.

45. Bras, R.L. Hydrology; Addison-Wesley: New York, NY, USA, 1990; p. 643.

46. Krapivin, V.F.; Phillips, G.W.; Nitu, C. A remote sensing-based modeling system to study the Aral-Caspian water regime. In Proceedings of the 16th International Conference on Control Systems and Computer Science, Bucharest, Romania, 22-25 May 2007; pp. 524-528.

47. Bortnik, V.N.; Chistyaeva, S.P. Aral Sea. In Hydrometeorology and Hydrochemistry of the Formar Soviet Union Seas; Terziev, F.S., Ed.; Hydrometeoizdat: Leningrad, Russia, 1990; pp. 3-195. (In Russian)

48. Ibrayev, R.A.; Özsoy, E.; Schrum, C.; Sur, H.I. Seasonal variability of the Caspian Sea three-dimensional circulation, sea level and air-sea interaction. Ocean Sci. 2010, 6, 311-329. [CrossRef]

49. Zavialov, P. Phisical Oceanography of the Drying Aral Sea; Springer: Chichester, UK, 2005; p. 149.

50. Dubovik, O. Multi-scale Targeting of Land Degradation in Northern Uzbekistan Using Satellite Remote Sensing. Ph.D. Thesis, University of Bonn, Bonn, Germany, 2013; p. 119.

51. Varotsos, C.A.; Nitu, C.; Krapivin, V.F. Global Ecoinformatics: Theory and Applications; Matrix Rom: Bucharest, Romania, 2018; p. 351.

52. Reyer, C.; Otto, I.M.; Albrecht, T.; Baarsch, F. Climate change impacts in Central Asia and their implications for development. Reg. Environ. Chang. 2015, 15, 1639-1650. [CrossRef]

53. Borodin, L.F.; Krapivin, V.F.; Kulikov, Y.u.N. Avia-monitoring complex for regional investigations of nature-economic situation. Probl. Desert Dev. 1987, 1, 80-88. (In Russian)

54. Krapivin, V.F.; Shutko, A.M. Information Technologies for Remote Monitoring of the Environment; Springer: Chichester, UK, 2012; p. 498.

55. Borodin, L.F.; Bortnik, V.N.; Krapivin, V.F.; Kuznetsov, N.G.; Kulikov, Y.u.N.; Minaeva, E.N. To the assessment of changes, elaboration of models for the functioning and remote sensing of aqua- and geoecosystems in the Aral Sea Basin. Probl. Desert Dev. 1987, 1, 71-80. (In Russian) 
56. Varotsos, C.A.; Krapivin, V.F. A new big data approach based on geoecological information-modeling system. Big Earth Data 2017, 1, 47-63. [CrossRef]

57. Kondratyev, K.Y.; Krapivin, V.F.; Phillips, G.W. Global Environmental Change: Modelling and Monitoring; Springer: Berlin, Germany, 2002; p. 316.

58. Kondratyev, K.Y.; Krapivin, V.F.; Savinikh, V.P.; Varotsos, C.A. Global Ecodynamics: A Multidimensional Analysis; Springer: Chichester, UK, 2004; p. 687.

59. Krapivin, V.F.; Long, B.T.; Rochon, G.L.; Hicks, D.R. A global simulation model as a method for estimation of the role of regional area in global change. In Proceedings of the Second Ho Chi Minh City Conference on Mechanics, Ho Chi Minh City, Vietnam, 24-25 September 1996; pp. 68-69.

60. Nihoul, J.C.J.; Zavialov, P.O.; Micklin, P.P. Dying and dead seas-Climatic versus anthropic causes. In Proceedings of the NATO Advanced Research Workshop on Dying and Dead Seas-Climatic Versus Anthropic Causes, Liège, Belgium, 7-10 May 2003; p. 383.

61. Mintzer, I.M. A matter of degrees: The potential for controlling the greenhouse effect. World Resour. Inst. Res. Rep. 1987, 15, 1-70.

62. Pohl, B.; Kramer, A.; Hull, W.; Blumstein, S.; Abdullaev, I.; Kazbekov, J.; Reznikova, T.; Strikeleva, E.; Interwies, E.; Görlitz, S. Rethinking Water in Central Asia: The Costs of Inaction and Benefits of Water Cooperation; CAREX: Berlin, Germany, 2017; p. 115.

(C) 2019 by the authors. Licensee MDPI, Basel, Switzerland. This article is an open access article distributed under the terms and conditions of the Creative Commons Attribution (CC BY) license (http://creativecommons.org/licenses/by/4.0/). 